\title{
The Relationship Between Psychological Contract Breach, Organizational Identification, and Organizational Agility Among Nursing Faculty Members
}

\author{
Yaldez Khairy Zein El Din ${ }^{1,2, ~ *, ~ G h a d a ~ M o h ~ S a m i r ~ E l ~ H e s s e w i ~}{ }^{2,3}$ \\ ${ }^{1}$ Nursing Administration Department, The British University in Egypt (BUE), El Sherouk, Egypt \\ ${ }^{2}$ Nursing Administration Department, Damanhour University, El Sherouk, Egypt \\ ${ }^{3}$ Department of Heath Sciences, Princess Nourah Bint Abdulrahman University, Riyadh, Saudi Arabia \\ Email address: \\ yaldez.zeineldin@bue.edu.eg (Y. K. Z. El Din), gmelhessewi@pnu.edu.sa (G. M. S. El Hessewi) \\ ${ }^{*}$ Corresponding author
}

\section{To cite this article:}

Yaldez Khairy Zein ElDin, Ghada Moh Samir El Hessewi. The Relationship Between Psychological Contract Breach, Organizational Identification, and Organizational Agility Among Nursing Faculty Members. American Journal of Nursing Science.

Vol. 8, No. 6, 2019, pp. 304-312. doi: 10.11648/j.ajns.20190806.13

Received: September 20, 2019; Accepted: October 11, 2019; Published: October 23, 2019

\begin{abstract}
Psychological contract is defined as the unwritten or hidden agreement between both the employers and the employees to ensure reciprocity and safe productive work environment. The concept of the relationship between Psychological Contract Breach (PCB) as one of many recognized antecedents of organizational identification has been emphasised for years. Organizational Identification (OI) is defined as the extent to which both the organisation and the employee's identities are overlapped. Organizational Identification (OI) has many benefits. For instance, it has a robust effect on the employees' cognitive abilities, attitude, and behavior including their organizational agility and acceptance to the external and internal environmental forces that induce changes rapidly. Organizational agility (OA) requires rapid adaptation of new services, technologies, and personnel in order to react successfully to sudden shifts or changes in the market. Aim: To determine the relationship between Psychological Contract Breach (PCB), Organizational Identification (OI), and Organizational Agility (OA). Design: A descriptive correlational research design is used. Setting: Faculty of Nursing, Damanhur University. Subjects: The study includes all faculty members $\mathrm{N}=200$, (56) academic staff, (85) non-academic (TA and Instructors), and (59) employees. Instrument: A questionnaire of 40 statements on a 5 point-Likert scale to measure (PCB), (OI) and (OA). Results: The highest mean percent score $(86.10 \pm 12.86)$ was for Organizational Identification (OI), while the lowest percent score $(66.68 \pm 12.0)$ was for overall PCB dimension. Overall PCB has a negative significant correlation with OI where $(\mathrm{r}=-0.609)$ and $\mathrm{p}=<0.001$. In relation to $\mathrm{OA}$, it has significant negative correlation with transactional $\mathrm{PCB}(\mathrm{r}=-0.225)$, relational $\mathrm{PCB}(\mathrm{r}=-$ 0.169), and OI ( $\mathrm{r}=-0.256)$. Recommendations: 1 . To conduct a qualitative study about Psychological Contract Breach in order to generate more information about employees' expectations. 2. To develop a training program for all the Faculty of Nursing staff members, which can enhance their cognitive abilities to be able to respond rapidly to any sudden changes in the market.
\end{abstract}

Keywords: Organizational Identification, Psychological Contract, Organizational Agility, Contract Breach, Changing Environment, Organizational Identity, Higher Education

\section{Introduction}

Nowadays, keeping employees satisfied in their workplace is an issue that requires great effort from the employer. Hence, applying the psychological contract will help the employers to improve employee satisfaction. Psychological contract is built on both employers and employees' mutual expectations of their roles and obligations [1]. Moreover, it is defined as unwritten or hidden agreement between employees and employers to ensure reciprocity and safe productive work environment [2]. Conway \& Coyle-Shapiro (2012) stated that in order to formulate a psychological contract, employees form subjective expectations for their employers as well as for themselves to maintain a fair and 
balanced mutual relationship. The employer will reciprocate if the employee meets his/her obligations [3]. Morrison \& Robinson (1997) argued that psychological contract breach (PCB) occurs when an employee thinks that the organization has failed to keep its promises despite his or her fulfilment of obligations [4].

Many previous studies have shown that PCBs lead to undesirable outcomes for employees and organizations, such as the presence of incivility towards other workers $[5,6]$ and the decrease in work engagement [7]. These outcomes, as part of a huge set of unwanted behavioral outcomes, are commonly conceptualized as counterproductive work behaviors (CWBs) [8]. Rousseau (2004) and Kim (2018) classified the psychological contracts (PCs) into two dimensions: Transactional and relational. Transactional PCs are recognised by their short duration, monetary, or economic terms and conditions in the employees' mutual exchange agreement with employers $[9,10]$. In this respect, researchers consider transactional PCs as an important part of the coworkers' relationship because the differences of wages and salary across organizations is the main reason of employee mobilization [11]. Relational PCs, in contrast, are long-term employment arrangements and include mutual trust, loyalty and socio-emotional exchanges often in the form of job security [9]. Both transactional and relational PCs are crucial and if breached, it will affect employee's perception of organizational identification. Research by Epitropaki (2013) has investigated the psychological contract breach and organizational identification [12]. Since then, a growing number of research has mobilized the concept of the relationship between psychological contract breach as one of many recognized antecedents for organizational identification $[1,13]$.

Organizational identification has been recognized as one practice of work identity. It was defined by Van Knippenberg \& Sleebos (2006) as the extent to which an organization identity and an employee's own identity overlap [14]. In other words, the more employees identify with their organization, the more the organization values, goals, and norms are included in employees' self-concept [15]. Moreover, it is well known that employees who powerfully identify with their work organizations are more loyal to their organization, more motivated, and better performers [16-18]. This leads researchers to embrace organizational identification as a "magic bullet" in the mission to improve employee's engagement and performance $[19,20]$. However, for organizational identification to be achieved, it depends on certain antecedents. In addition, if properly developed it will have more favorable outcomes. Organizational identification has many benefits. For instance, it has a robust effect on a large range of employee's cognitive abilities, attitude and behavior including their organizational agility and acceptance to external and internal environmental forces that induce changes rapidly [20-22].

Organizational agility is considered a core competency; it is an ongoing process that is a matter of becoming not being $[23,24]$. Furthermore, Organizational agility (OA) requires rapid adaptation of new services, updated technologies and personnel to meet the shift in the market requirements [2527]. Environmental shifts are considered one of many forces that jeopardize the organization existence and reputation if the organization members are not resilient to these forces. Many forces for change are present nowadays and they should be highly considered. These forces include changes in government regulations especially in the higher education sector, intensifying competition and changing customer demands with rapidly evolving technology [28-30]. Many previous studies have shown that all efforts of changes were unsuccessful [31, 32]. In the higher education in Egypt, a great reform in the universities has been developed, which initiates certain forces on the educational environment and therefore requires an agile workforce that can work with all these changes easily and effectively [33].

Studies on Psychological Contract Breach (PCB) have been done in relation to different factors such as age [34], tenure [35], personality [36] and counterproductive behavior [37, 38]. Another research was conducted by Conway \& Coyle-Shapiro (2012) to detect the connection between PCB and organizational citizenship behavior [3]. Furthermore, Epitropaki (2013) studied the relationship between PCB and organization identification [12]. Other researches addressing the relationship between PCB and organization identification and agility are limited. The connection between PCB, organization identification and agility has received little attention in the literature [39]. In Egypt, up to the knowledge of the researchers, no study has been conducted in academic setting that investigates the relationship between psychological contract breach, organizational identification and agility. Therefore, the current study is conducted in order to study the concept of PCB as an antecedent for organizational identification and agility in a higher education reform era. The results of the current study have important implications for University presidents, Faculty deans and human resources professionals. The current changes that occur in the higher education impose the deans and other decision makers to have highly resilient staff. In order to achieve this aim, the staff should feel that their psychological needs are fulfilled and they should also identify the organization where they work.

\section{Materials and Methods}

\subsection{Materials}

\subsubsection{Aim of the Study}

To determine the relationship between Psychological Contract Breach (PCB), Organizational Identification (OI) and Organizational Agility (OA).

\subsubsection{Study Design}

A descriptive correlational research design is used in this study.

\subsubsection{Study Questions}

1. What is the level of (PCB) of Nursing Faculty members?

2. What is the level of Organizational Identification (OI) 
of Nursing Faculty members?

3. What is the level of Organizational Agility (OA) of Nursing Faculty members?

4. What is the relationship between (PCB), (OI), and (OA).

\subsubsection{Setting}

This study was conducted in the Faculty of Nursing, Damanhour University. This setting was selected because the faculty is considered a newly established one since (2006) as compared to other nursing faculties across Egypt. Another cause is that the Faculty of Nursing, Damanhour University is preparing to receive the national accreditation, which compels the faculty staff to adopt a lot of changes in every facets of their work, professionally and personally.

\subsubsection{Subjects}

The study included all faculty members $\mathrm{N}=200$, (56) academic staff, (85) non-academic (TA and Instructors) and (59) employees.

\subsubsection{Study Instrument}

The instrument was developed by the researchers after thorough review of related literature [40-54]. It has 40 statements on a 5 point-Likert scale where $(5=$ Strongly agree and $1=$ Strongly Disagree). It is divided into four parts as follow:

Part one: The demographic data of the faculty members in terms of age, department, job title, category (academic or non-academic) and years of experience.

Part two: The Psychological Contract Breach (PCB) scale (16 statements) and it contains two sub-dimensions: Transactional (PCB) (3 Statements) and Relational (PCB) (13 statements). The highest score is 90 and the lowest is 18 for the whole scale. This part measures the extent of the PCB's perception of the Faculty of Nursing Members. The highest scores denote a high perception of Psychological Contract Breach (PCB).

Part three: Organizational Identification (OI) scale consists of (5 statements). This part measures the extent to which the Faculty of Nursing Members identify their organization. The lowest score is 5 and the highest score is 25 . When the scores are high, this means that (OI) is high.

Part four: Organizational Agility (OA) scale consists of (19 statements) on a 5 point likert scale ranging from strongly agree $=5$ to strongly disagree $=1$. The lowest score is 95 and the highest score is 19. The more the score, the higher the Organizational Agility.

\subsection{Methods of Data Collection}

1. An official permission was obtained from the faculty of nursing to agree on data collection.

2. After the development of instrument, it was translated into Arabic language by the researchers to suit its utilization in Egyptian community, and to ensure consistency among study participants. Questionnaire was submitted to them in the Arabic language.

\subsubsection{Validity of the Instruments}

The translated study instrument was revised by three bilingual academic professionals. A back-translation was conducted by the researcher and revised by another two bilingual translators to assure that the translated questionnaire reserved the same meanings. To establish content validity, the questionnaire was submitted to a jury composed of five experts affiliated to different universities but all are Nursing Administration professors and Assistant professors to prove the relevance of instrument statements to the study objectives. Based on the feedback, necessarily modifications were done on the instrument to be more compatible with Egyptian community.

3. Reliability of the Arabic version of the study instruments parts were assessed using Cronbach's alpha co-efficient test. Part two: measuring PCB $(\alpha=.92)$, part three: measuring OI $(\alpha=.88)$ and part four measuring OA $(\alpha=.90)$.

4. A pilot study was carried out on approximately $10 \%$ of the sample $(\mathrm{N}=20)$, who were excluded from the study subjects. The pilot study was done to test feasibility, clarity, applicability, and facility of the instrument. Accordingly, the necessary modifications were done.

5. Instrument was written on a google form document, and the link was sent to the staff members through the official Whatsapp group of the faculty, and an announcement was made. Then, the responses were sent to the researchers only via email.

6. The researchers introduced and explained the aim of the study to the participants before conducting the questionnaire.

7. The data collection started in May 2019 and ended in July 2019, with a gentle reminder sent to participants in June 2019.

\subsubsection{Ethical Considerations}

1. The purpose of the study was written on the first page of the questionnaire.

2. Confidentiality of the data and anonymity of the study subjects were maintained.

3. The subject right to discontinue the questionnaire was ensured.

\subsubsection{Statistical Analysis}

Data were fed to the computer and analyzed using IBM SPSS software package version 20.0 [55]. Qualitative data were described using number and percent. Quantitative data were described using range (minimum and maximum), mean, and standard deviation. Significance of the obtained results was judged at the $5 \%$ level.

The used tests were

1. Pearson coefficient

To correlate between two normally distributed quantitative variables.

2. Student t-test

For normally distributed quantitative variables, to compare between two studied groups.

3. F-test (ANOVA) 
For normally distributed quantitative variables, to compare between more than two groups.

\section{Results}

This section presents demographic characteristics and results of the descriptive and inferential statistical analyses of the named variables. Results are presented for each research question. The main variables that were measured in this study included overall Psychological Contract Breach (PCB), Organizational Identification (OI), and Organizational Agility (OA).

The current study aims to determine the relationship between Psychological Contract Breach (PCB), Organizational Identification (OI) and Organizational Agility (OA).

Study questions:

1. What is the level of (PCB) of Nursing Faculty members?

2. What is the level of Organizational Identification (OI) of Nursing Faculty members?

3. What is the level of Organizational Agility (OA) of Nursing Faculty members?

4. What is the relationship between PCB and Organizational Identification (OI), and between it and agility?

Table 1. Demographic characteristics of Nursing Faculty members $(n=200)$.

\begin{tabular}{lll}
\hline Socio demographic data & No. & \% \\
\hline Job Title & & \\
Employees & 59 & 29.5 \\
Clinical instructor & 85 & 42.5 \\
Academic member & 56 & 28.0 \\
Age (years) & & \\
20<30 & 16 & 8.0 \\
$30<40$ & 76 & 38.0 \\
$40<50$ & 83 & 41.5 \\
$50<60$ & 25 & 12.5 \\
Gender & & \\
Female & 173 & 86.5 \\
Male & 27 & 13.5 \\
Years of experience & & \\
$<5$ & 16 & 8.0 \\
$5<10$ & 17 & 8.5 \\
$11<20$ & 100 & 50.0 \\
$21<30$ & 67 & 33.5 \\
Department & & \\
Administrative departments & 60 & 30.0 \\
Academic Departments: Community Health Ng. & 29 & 14.5 \\
Ng. Administration & 16 & 8.0 \\
Pediatrics Ng. & 14 & 7.0 \\
Adult and Med. Surg. Ng. & 17 & 8.5 \\
Ng. Education & 18 & 9.0 \\
Obstetric Ng. & 17 & 8.5 \\
\hline
\end{tabular}

Table 3. Correlation matrix between Psychological Contract Breach (PCB), Organizational Identification (OI) and Organizational Agility (OA) domains Table 3.

\begin{tabular}{|c|c|c|c|c|c|c|}
\hline & & Transactional & Relational & Overall PCB & OI & $\mathbf{O A}$ \\
\hline \multirow{5}{*}{ PCB } & \multirow{2}{*}{ Transactional } & $\mathrm{r}$ & $0.478^{*}$ & $0.665^{*}$ & $-0.586^{*}$ & $-0.225^{*}$ \\
\hline & & $\mathrm{p}$ & $<0.001^{*}$ & $<0.001^{*}$ & $<0.001^{*}$ & $0.001^{*}$ \\
\hline & \multirow{2}{*}{ Relational } & $\mathrm{r}$ & & $0.843^{*}$ & $-0.338^{*}$ & $-0.169^{*}$ \\
\hline & & $\mathrm{p}$ & & $<0.001^{*}$ & $<0.001^{*}$ & $0.017^{*}$ \\
\hline & Overall PCB & $\mathrm{r}$ & & & $-0.609^{*}$ & -0.061 \\
\hline
\end{tabular}

\begin{tabular}{lll}
\hline Socio demographic data & No. & \% \\
\hline Psychiatric Ng. & 11 & 5.5 \\
Gerontology Ng. & 8 & 4.0 \\
Critical Care Ng. & 10 & 5.0 \\
\hline
\end{tabular}

Table 1 shows the demographic characteristics of the Faculty of Nursing staff members. It is noticed that $(42.5 \%)$ of respondents were clinical instructors, while (28\%) were academic staff. Regarding the age group among all staff members, $(41.5 \%)$ of participants are aged 41 to less than 50 while only $(8 \%)$ are aged from 20 to less than 30 . The majority of respondents $(86.1 \%)$ are females and $(50 \%)$ have from 11 to 20 years of experience. Furthermore, $(30 \%)$ of the participants are from the administrative departments. As for the academic departments, the highest percentage $(14.5 \%)$ is from Community Health Nursing and the lowest percentage $(4 \%)$ is from Gerontology Nursing.

Table 2. Mean and Mean percent score of the studied samples regarding Identification (OI) and Organizational Agility (OA) domains $(n=200)$.

\begin{tabular}{lll}
\hline PCB (Dimensions) & Total score & \% score \\
\hline Transactional & & \\
Min. - Max. & $3.0-9.0$ & $12.50-87.50$ \\
Mean \pm SD. & $6.18 \pm 1.86$ & $52.19 \pm 23.29$ \\
Relational & & \\
Min. - Max. & $33.0-60.0$ & $38.46-90.38$ \\
Mean \pm SD. & $48.83 \pm 6.12$ & $68.90 \pm 11.77$ \\
Overall PCB & & \\
Min. - Max. & $37.0-68.0$ & $36.67-88.33$ \\
Mean \pm SD. & $55.0 \pm 7.20$ & $66.68 \pm 12.0$ \\
Organizational Identification & & \\
Min. - Max. & $15.0-25.0$ & $50.0-100.0$ \\
Mean \pm SD. & $22.22 \pm 2.57$ & $86.10 \pm 12.86$ \\
Organizational Agility & & \\
Min. - Max. & $54.0-90.0$ & $46.05-93.42$ \\
Mean \pm SD. & $74.47 \pm 8.52$ & $72.99 \pm 11.21$ \\
\hline
\end{tabular}

Table 2 illustrates the mean and mean percent score of Nursing Faculty staff members regarding the study dimensions. In relation to Psychological Contract Breach (PCB) sub-dimensions, it could be observed that relational PCB scored a mean percentage $(68.90 \pm 11.77)$ higher than transactional $\mathrm{PCB}$, which has a mean percent score $=(68.90 \pm 11.77)$. When comparing the three dimensions, it can be observed that the highest mean percent score $(86.10 \pm 12.86)$ is for Organizational Identification (OI), while the lowest percent score $(66.68 \pm 12.0)$ is for overall (PCB) dimension. Psychological Contract Breach (PCB) as antecedents, Organizational 


\begin{tabular}{|c|c|c|c|c|c|}
\hline & Transactional & Relational & Overall PCB & OI & $\mathbf{O A}$ \\
\hline \multirow{3}{*}{ Organizational Identification (OI) } & 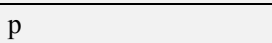 & & & $<0.001^{*}$ & 0.387 \\
\hline & $\mathrm{r}$ & & & & $-0.256^{*}$ \\
\hline & $\mathrm{p}$ & & & & $<0.001^{*}$ \\
\hline \multirow{2}{*}{ Organizational Agility (OA) } & $\mathrm{r}$ & & & & \\
\hline & $\mathrm{p}$ & & & & \\
\hline
\end{tabular}

r: Pearson coefficient.

*: Statistically significant at $\mathrm{p} \leq 0.05$

Table 3 illustrates the correlation matrix between PCB, OI, OA. It could be seen that transactional $\mathrm{PCB}$ has positive significant correlations with relational $\mathrm{PCB}$, Over all $\mathrm{PCB}$ $(\mathrm{r}=0.478,0.665)$ respectively, while it has negative correlation with $(\mathrm{O} I)(\mathrm{r}=-0.586)$ where $\mathrm{p}=<0.001$ for all. Regarding the relational PCB, it could be observed that it has positive significant correlation with Over all PCB $(\mathrm{r}=0.843)$, while it has a negative correlation with $\mathrm{O}$ I where $(\mathrm{r}=-0.338)$ and $\mathrm{p}=<0.001$ for both dimensions. In relation to overall $\mathrm{PCB}$, it has a negative significant correlation with OI where $(\mathrm{r}=-0.609)$ and $\mathrm{p}=<0.001$. In relation to $\mathrm{OA}$, it has significant negative correlations with transactional PCB $(\mathrm{r}=-0.225)$, with relational $\mathrm{PCB}(\mathrm{r}=-0.169)$ and with $\mathrm{OI}(\mathrm{r}=-0.256)$.

Table 4. Test of significance between sub-dimensions and overall PCB, Organizational Identification (OI) and Organizational Agility (OA) in relation to demographic characteristics.

\begin{tabular}{|c|c|c|c|c|c|}
\hline & Transactional PCB & relational & Overall PCB & OI & $\mathbf{O A}$ \\
\hline & Mean \pm SD. & Mean \pm SD. & Mean \pm SD. & Mean \pm SD. & Mean \pm SD. \\
\hline \multicolumn{6}{|l|}{ Job title } \\
\hline Employees & $54.87 \pm 27.37$ & $71.41 \pm 13.8$ & $69.21 \pm 14.63$ & $86.44 \pm 14.59$ & $75.36 \pm 8.82$ \\
\hline Academic member & $54.46 \pm 21.38$ & $68.17 \pm 9.76$ & $66.34 \pm 9.92$ & $87.05 \pm 10.99$ & $71.43 \pm 12.98$ \\
\hline $\mathrm{F}(\mathrm{p})$ & $1.555(0.214)$ & $1.957(0.144)$ & $2.058(0.130)$ & $0.364(0.695)$ & $2.008(0.137)$ \\
\hline \multicolumn{6}{|l|}{ Age (years) } \\
\hline $31<40$ & $65.79 \pm 24.01$ & $69.91 \pm 15.31$ & $69.36 \pm 16.12$ & $89.61 \pm 12.38$ & $74.72 \pm 9.16$ \\
\hline $41<50$ & $41.42 \pm 13.66$ & $69.76 \pm 9.05$ & $65.98 \pm 8.21$ & $85.06 \pm 12.68$ & $76.33 \pm 8.55$ \\
\hline $51<60$ & $59.5 \pm 24.28$ & $67.92 \pm 9.33$ & $66.8 \pm 8.06$ & $87.2 \pm 10.52$ & $63.42 \pm 17.05$ \\
\hline $\mathrm{F}(\mathrm{p})$ & $26.955^{*}\left(<0.001^{*}\right)$ & $2.764^{*}\left(0.043^{*}\right)$ & $4.901^{*}\left(0.003^{*}\right)$ & $8.396^{*}\left(<0.001^{*}\right)$ & $17.393^{*}\left(<0.001^{*}\right)$ \\
\hline \multicolumn{6}{|l|}{ Gender } \\
\hline Female & $46.68 \pm 20.03$ & $66.36 \pm 10.33$ & $63.74 \pm 9.91$ & $84.16 \pm 12.6$ & $71.9 \pm 11.68$ \\
\hline Male & $87.5 \pm 0.0$ & $85.19 \pm 5.98$ & $85.49 \pm 5.18$ & $98.52 \pm 5.51$ & $79.97 \pm 1.05$ \\
\hline $\mathrm{T}(\mathrm{p})$ & $26.804^{*}\left(<0.001^{*}\right)$ & $13.507^{*}\left(<0.001^{*}\right)$ & $17.402^{*}\left(<0.001^{*}\right)$ & $10.042^{*}\left(<0.001^{*}\right)$ & $8.863^{*}\left(<0.001^{*}\right)$ \\
\hline$<5$ & $25.0 \pm 0.0$ & $54.57 \pm 11.25$ & $50.63 \pm 9.75$ & $70.0 \pm 7.07$ & $65.05 \pm 9.76$ \\
\hline $5<10$ & $52.94 \pm 12.91$ & $61.43 \pm 5.71$ & $60.29 \pm 5.66$ & $80.29 \pm 13.28$ & $78.64 \pm 8.82$ \\
\hline $11<20$ & $57.63 \pm 25.8$ & $72.23 \pm 10.81$ & $70.28 \pm 11.9$ & $88.35 \pm 12.51$ & $76.59 \pm 9.45$ \\
\hline $21<30$ & $50.37 \pm 19.21$ & $69.26 \pm 11.15$ & $66.74 \pm 9.96$ & $88.06 \pm 11.25$ & $68.07 \pm 11.69$ \\
\hline $\mathrm{F}(\mathrm{p})$ & $10.554^{*}\left(<0.001^{*}\right)$ & $15.765^{*}\left(<0.001^{*}\right)$ & $17.744^{*}\left(<0.001^{*}\right)$ & $13.065^{*}\left(<0.001^{*}\right)$ & $14.219^{*}\left(<0.001^{*}\right)$ \\
\hline \multicolumn{6}{|l|}{ Department } \\
\hline Adminisatration & $54.38 \pm 27.41$ & $71.31 \pm 13.7$ & $69.06 \pm 14.55$ & $86.58 \pm 14.51$ & $75.0 \pm 9.17$ \\
\hline Nurs. Community & $40.95 \pm 19.74$ & $66.31 \pm 11.88$ & $62.93 \pm 11.69$ & $81.55 \pm 12.68$ & $75.54 \pm 8.33$ \\
\hline Nurs. Adm & $57.03 \pm 18.8$ & $66.11 \pm 10.22$ & $64.9 \pm 10.32$ & $87.81 \pm 11.83$ & $71.38 \pm 12.47$ \\
\hline Pediatrics & $44.64 \pm 14.47$ & $64.29 \pm 13.4$ & $61.67 \pm 10.98$ & $85.0 \pm 13.01$ & $72.84 \pm 8.15$ \\
\hline Med. Surg. & $63.97 \pm 26.47$ & $72.4 \pm 10.68$ & $71.27 \pm 11.79$ & $85.59 \pm 12.1$ & $71.83 \pm 15.87$ \\
\hline Nurs. Edu. & $54.17 \pm 19.17$ & $67.52 \pm 8.92$ & $65.74 \pm 8.62$ & $87.5 \pm 11.28$ & $74.34 \pm 12.53$ \\
\hline Obs. & $45.59 \pm 18.19$ & $69.68 \pm 12$ & $66.47 \pm 11.64$ & $87.94 \pm 12.75$ & $71.28 \pm 9.59$ \\
\hline Psych & $59.09 \pm 24.43$ & $68.36 \pm 7.71$ & $67.12 \pm 9.16$ & $87.27 \pm 10.34$ & $67.22 \pm 15.37$ \\
\hline Ng. Gernt & $57.81 \pm 18.82$ & $69.71 \pm 8.71$ & $68.13 \pm 7.21$ & $88.75 \pm 13.02$ & $71.05 \pm 14.41$ \\
\hline
\end{tabular}

$\mathrm{t}$ : Student t-test F: F for ANOVA test.

$\mathrm{p}$ : $\mathrm{p}$ value for association between different categories *: Statistically significant at $\mathrm{p} \leq 0.05$.

Table 4 shows the significant differences between study's variables and the participants' demographic characteristics. It could be observed that regarding the age group, there were significant differences between different age groups and transactional $\mathrm{PCB}$ where $\mathrm{p}=(0.001)$, relational where $\mathrm{p}=(0.043)$, overall PCB where $\mathrm{p}=(0.003)$, OI where $\mathrm{p}=(0.001)$ and OA where $\mathrm{p}=(0.001)$. With the highest score for transactional $\mathrm{PCB}$, relational $\mathrm{PCB}$, overall $\mathrm{PCB}$ and $\mathrm{OI}$ were for the age group ranged from 31 to less than 40 , while the highest score for OA was for those aged from 41 to less than 50. Regarding the gender, the highest scores for all study variables were for male and there were significant in all study variables where $p=(0.001)$. As for years of experience, it is observed from the table there were significant 
differences between different years of experience groups and transactional PCB where $\mathrm{p}=(0.001)$, relational where $\mathrm{p}=(0.001)$, overall PCB where $\mathrm{p}=(0.001)$, OI where $\mathrm{p}=(0.001)$ and OA where $\mathrm{p}=(0.001)$. With the highest score for transactional $\mathrm{PCB}$, relational $\mathrm{PCB}$, overall $\mathrm{PCB}$ and $\mathrm{OI}$ were for the those experienced from 11 to less than 20 years, while the highest score for OA was for those experienced from 5 to less than 10 years. Only transactional PCB differed significantly with different faculty departments where $\mathrm{p}=(0.048)$ where Community Health Nursing scored the lowest percent $(40.95 \pm 19.74)$ and the Medical Surgical Nursing department scored the highest scores (63.97 \pm 26.47$)$.

\section{Discussion}

In a new era which is signaled by ambiguity, anxiety, and adjustments, it has become more critical than ever to confirm advanced and healthy relationships between employees and their employers in terms of proper fulfillment of psychological contract [56]. Many studies have been conducted to investigate the different antecedents of organizational identification during a transactional process especially during a merger $[57,58]$. The current study is conducted in order to investigate the relationship between Psychological Contract Breach (PCB), Organizational Identification (OI) and Organizational Agility (OA).

The results of the current study show that the highest mean percent score is for Organizational Identification (OI) while the lowest percent score was for overall PCB dimension. This could be attributed to the nature of Faculty of Nursing, Damanhur University as the interpersonal relationships within the study setting are strong and there are a lot of social activities and gathering inside the faculty which from the researchers' point of view is a major cause for the high OI and the feeling of oneness. Regarding the PCB dimension and the low score that it gets, this finding could be a reason of that the public and governmental sector is not considered a promising setting especially in terms of transactional PC and the monetary rewards. Another cause could be the low expectations of the staff members as there are all governed under the labor law of the country and they do not expect more than what they already know and wait. The same results were found by Ashforth et al (2011) [58] and by Colman \& Lunnan (2011) [59]. On the other hand, Millward \& Haslam (2013) reported the contrast [60].

The present study findings reported that overall PCB has a negative significant correlation with $\mathrm{OI}$. This means that whenever the employees feel their psychological contracts breached, they have a low sense of organizational identification. This is an expected finding as it is well known that when the person feels his needs and motives unsatisfied in their workplace, they get less attached and committed to the place where they work and therefore they identify less their organization. On the same line, Brickson (2013) studied how multiple motives formulate and affect organizational identification and supported the same result [61]. Also, Lapointe et al (2013) reported an identical finding and stressed the important role of supervisor to embody the organization's identification [62]. The same was concluded by Bayram and Zeybek (2014) who found a negative correlation between organizational identification and transactional dimensions of the psychological contract of employees [63]. Sulu and colleagues (2010) recommended conducting studies for the establishment of interrelations of employees in organizational development will allow enhancement of organizational identification [64].

The current study detected that Organizational Agility (OA) has significant negative correlations with transactional PCB and relational PCB as well as Organizational Identification (OI). This wants to say that the more Nursing Faculty members feel that their motives and needs broken, the less they identify their organization and the less they become flexible and accept new changes. This is also a normal finding as whenever the person feels satisfied, they experience resistance to changes and they prefer to maintain their status quo. The same was found by Oreg and Sverdlik (2011) who studied a university campus relocation, and reported that there was an interaction between identification and dispositional resistance in which employees' reactions to the change were ambivalent when organizational identification was high [65]. Contrast to these findings, Madsen, Miller and John (2005) reported organizational identification to be positively related to readiness for change [66]. Also, Bartels et al (2009) found that perceived psychological contract fulfillment determines organizational identification during change processes. Furthermore, they reported that employees who possess high identification are more oriented toward organizational interests [67].

The findings of the current study conclude significant differences between different age groups and transactional $\mathrm{PCB}$, relational $\mathrm{PCB}$, overall $\mathrm{PCB}$, OI and $\mathrm{OA}$. With the highest score for transactional $\mathrm{PCB}$, relational $\mathrm{PCB}$, overall $\mathrm{PCB}$ and $\mathrm{OI}$ are for the age group ranged from 31 to less than 40. This is a normal finding as this age group is considered the mid of professional career and they are seeking for selfimprovement and development, thus they highly identify their organization and they feel their psychological contract and motives fulfilled. Likewise, other studies found the same while stressing that later career stages and aged employees may have an intensified reaction to PCB [68, 69]. Regarding the gender, the study finding showed that gender had significant differences in all study variables. The contrast was found by Khalili and Asmawi (2012) [70] and Bayram and Zeybek (2016) [7] who found that there is no significant correlation between gender and psychological contract. Also, Edward and Peccei (2010) detected there were no significant differences between gender and organizational identification [71].

As for years of experience, the study found that there were significant differences between different years of experience groups and transactional $\mathrm{PCB}$, relational, overall $\mathrm{PCB}, \mathrm{OI}$ and $\mathrm{OA}$. With the highest score for transactional $\mathrm{PCB}$, relational $\mathrm{PCB}$, overall $\mathrm{PCB}$ and $\mathrm{OI}$ were for those experienced from 11 to less than 20 years. These findings are 
expected as the more years spent in the workplace, the more the employees get used to the work structure and their psychological contract are to somehow fulfilled with also more understanding to the leadership style and the nature of the organization. On the other hand, the highest score for OA was for those experienced from 5 to less than 10 years. This also is a normal finding because those who are less experienced are more opened to change, more flexible and ambitious, and are more agile than more experienced employees.

\section{Conclusion and Recommendations}

The current study was conducted in order to determine the relationship between psychological contract breach, organizational identification and organizational agility. The study reveals that there are positive significant relationships between overall PCB and its sub-dimensions, OI. On the other hand, negative significant correlation was reported between OA and overall PCB and OI. The current study has some implications for faculty deans. For instance, avoiding giving promises instead providing employees with complete, accurate information regarding their job. Also, the deans should exert more efforts to fulfill their obligations towards their employees. They should also have persistent chain of communication with their employees to avoid any misunderstanding or inaccurate concepts regarding their roles. In this respect, the faculty dean can guarantee a high level of organizational identification and more flexible staff during the change process.

Based on concluded results, the study recommended the following:

1. To conduct a qualitative study about Psychological Contract Breach so it can generate more information about employees' expectations.

2. To develop a comparative study between governmental and private faculties.

3. To develop training program for all Faculty of Nursing staff members about change and resistance to change and how to augment their agility and flexibility in highly changing environment.

\section{References}

[1] Vantilborgh T, Bidee J, Pepermans R, Griep Y, Hofmans J. Antecedents of psychological contract breach: The role of job demands, job resources, and affect. PloS one. 2016 May 12; 11 (5): $\mathrm{e} 0154696$

[2] Korte R, Mercurio ZA. Pragmatism and human resource development: Practical foundations for research, theory, and practice. Human Resource Development Review. 2017 Mar; 16 (1): 60-84.

[3] Conway N, Coyle-Shapiro JA. The reciprocal relationship between psychological contract fulfilment and employee performance and the moderating role of perceived organizational support and tenure. Journal of occupational and Organizational Psychology. 2012 Jun; 85 (2): 277-99.
[4] Morrison EW, Robinson SL. When employees feel betrayed: A model of how psychological contract violation develops. Academy of management Review. 1997 Jan 1; 22 (1): 226-56.

[5] Bordia P, Restubog SL, Tang RL. When employees strike back: investigating mediating mechanisms between psychological contract breach and workplace deviance. Journal of Applied Psychology. 2008 Sep; 93 (5): 1104.

[6] Sayers JK, Sears KL, Kelly KM, Harbke CR. When employees engage in workplace incivility: The interactive effect of psychological contract violation and organizational justice. Employee Responsibilities and Rights Journal. 2011 Dec 1; 23 (4): 269-83.

[7] Agarwal UA, Bhargava S. Effects of psychological contract breach on organizational outcomes: Moderating role of tenure and educational levels. Vikalpa. 2013 Jan; 38 (1): 13-26.

[8] Shoss MK, Jundt DK, Kobler A, Reynolds C. Doing bad to feel better? An investigation of within-and between-person perceptions of counterproductive work behavior as a coping tactic. Journal of Business Ethics. 2016 Sep 1; 137 (3): 571-87.

[9] Rousseau DM. Psychological contracts in the workplace: Understanding the ties that motivate. Academy of Management Perspectives. 2004 Feb 1; 18 (1): 120-7.

[10] Kim TT, Karatepe OM, Lee G. Psychological contract breach and service innovation behavior: psychological capital as a mediator. Service Business. 2018 Jun 1; 12 (2): 305-29.

[11] Kerr SP, Kerr WR. Economic impacts of immigration: A survey. National Bureau of Economic Research; 2011 Jan 27. Available at: https://www.nber.org/papers/w16736.pdf Accessed in July 2019.

[12] Epitropaki O. A multi-level investigation of psychological contract breach and organizational identification through the lens of perceived organizational membership: Testing a moderated-mediated model. Journal of Organizational Behavior. 2013 Jan; 34 (1): 65-86.

[13] Chernyak-Hai L, Tziner A. Relationships between counterproductive work behavior, perceived justice and climate, occupational status, and leader-member exchange. Revista de Psicología del Trabajo y de las Organizaciones. 2014 Apr 1; 30 (1): 1-2.

[14] Van Knippenberg D, Sleebos E. Organizational identification versus organizational commitment: self-definition, social exchange, and job attitudes. Journal of Organizational Behavior: The International Journal of Industrial, Occupational and Organizational Psychology and Behavior. 2006 Aug; 27 (5): 571-84.

[15] Carmeli A, Gilat G, Waldman DA. The role of perceived organizational performance in organizational identification, adjustment and job performance. Journal of Management Studies. 2007 Sep; 44 (6): 972-92.

[16] Blader SL, Tyler TR. Testing and extending the group engagement model: Linkages between social identity, procedural justice, economic outcomes, and extrarole behavior. Journal of applied psychology. 2009 Mar; 94 (2): 445.

[17] Lee ES, Park TY, Koo B. Identifying organizational identification as a basis for attitudes and behaviors: A metaanalytic review. Psychological bulletin. 2015 Sep; 141 (5): 1049. 
[18] Walumbwa FO, Avolio BJ, Zhu W. How transformational leadership weaves its influence on individual job performance: The role of identification and efficacy beliefs. Personnel psychology. 2008 Dec; 61 (4): 793-825.

[19] Ashforth BE. Distinguished scholar invited essay: Exploring identity and identification in organizations: Time for some course corrections. Journal of Leadership \& Organizational Studies. 2016 Nov; 23 (4): 361-73.

[20] Galvin BM, Lange D, Ashforth BE. Narcissistic organizational identification: Seeing oneself as central to the organization's identity. Academy of Management Review. 2015 Apr; 40 (2): 163-81.

[21] He H, Brown AD. Organizational identity and organizational identification: A review of the literature and suggestions for future research. Group \& Organization Management. 2013 Feb; 38 (1): 3-5.

[22] Bartels J, Douwes R, De Jong M, Pruyn A. Organizational identification during a merger: Determinants of employees' expected identification with the new organization. British Journal of Management. 2006 Mar; 17 (S1): S49-67.

[23] Alzoubi K, Hamasha MM, Lu S, Sammakia B. Bending fatigue study of sputtered ITO on flexible substrate. Journal of Display Technology. 2011 Sep 19; 7 (11): 593-600.

[24] Rahimiatani A, Zare H, Yazdani H. Increasing Organizational Agility based on Effective Meta-Organizational Parameters. Postmodern Openings/Deschideri Postmoderne. 2018 Dec 1; 9 (4).

[25] Holbeche L. The Agile Organization: How to build an innovative, sustainable and resilient business. Kogan Page Publishers; 2015 Jun 3.

[26] Al-Haddad S, Kotnour T. Integrating the organizational change literature: a model for successful change. Journal of Organizational Change Management. 2015 Apr 13; 28 (2): 234-62.

[27] Meyer P. Agility shift: Creating agile and effective leaders, teams, and organizations. Routledge; 2016 Nov 3.

[28] Yeadon-Lee A. Lead and disrupt: How to solve the innovators dilemma. Action Learning: Research and Practice. 2018; 15 (1): 72-3. https: //doi.org/10.1080/14767333.2017.1414674.

[29] Worley CG, Williams TD, Lawler III EE. The agility factor: Building adaptable organizations for superior performance. John Wiley \& Sons; 2014 Aug 4.

[30] Nafei WA. Organizational agility: the key to improve organizational performance. International Business Research. 2016; 9 (3): 97-111.

[31] Kotter JP. Accelerate: Building strategic agility for a fastermoving world. Harvard Business Review Press; 2014 Feb 25.

[32] Aguirre D, Alpern M. 10 principles of leading change management. Strategy + Business; 2014 Jun 6. 1-10.

[33] Cygan A. Higher Education Reform in Egypt: Putting Students at The Center. March 2019. Accessed in: September 2019, Available

at: https://www.gpgovernance.net/blog/higher-education-reformin-egypt-putting-students-at-the-centre/.

[34] Bal PM, De Lange AH, Jansen PG, Van Der Velde ME. A longitudinal study of Age-Related differences in reactions to psychological contract breach. Applied Psychology. 2013 Jan; 62 (1): 157-81. doi: 10.1111/j.1464-0597.2012.00524.x.

[35] Payne SC, Culbertson SS, Lopez YP, Boswell WR, Barger EJ. Contract breach as a trigger for adjustment to the psychological contract during the first year of employment. Journal of Occupational and Organizational Psychology. 2015 Mar; 88 (1): 41-60. doi: 10.1111/joop.12077.

[36] O'Neill TA, Hastings SE. Explaining workplace deviance behavior with more than just the "Big Five". Personality and Individual Differences. 2011 Jan 1; 50 (2): 268-73.

[37] Ahmed E, D'Netto B, Chelliah J, Fein E. Psychological contract breach: Consequences of unkept promises of permanent employment. Contemporary Management Research. 2016 Jun 29; 12 (2).

[38] Anjum MA, Parvez A. Counterproductive behavior at work: A comparison of blue collar and white collar workers. Pakistan Journal of Commerce and Social Sciences (PJCSS). 2013; 7 (3): 417-34.

[39] Jamil A, Raja U, Darr W. Psychological contract types as moderator in the breach-violation and violation-burnout relationships. The Journal of psychology. 2013 Sep 1; 147 (5): 491-515. doi: 10.1080/00223980.2012.717552.

[40] Coyle-Shapiro JA, Conway N. Exchange relationships: Examining psychological contracts and perceived organizational support. Journal of applied psychology. 2005 Jul; 90 (4): 774.

[41] Harrington JR, Lee JH. What drives perceived fairness of performance appraisal? Exploring the effects of psychological contract fulfillment on employees' perceived fairness of performance appraisal in US federal agencies. Public Personnel Management. 2015 Jun; 44 (2): 214-38.

[42] Zagenczyk TJ, Cruz KS, Woodard AM, Walker JC, Few WT, Kiazad K, Raja M. The moderating effect of Machiavellianism on the psychological contract breach-Organizational identification/disidentification relationships. Journal of Business and Psychology. 2013 Sep 1; 28 (3): 287-99.

[43] Jin Kim H, Shin B, Lee H. The mediating role of psychological contract breach in IS outsourcing: inter-firm governance perspective. European Journal of Information Systems. 2013 Sep 1; 22 (5): 529-47.

[44] Anderson BK. Psychological contracts: A feature based approach to understanding transactional and relational contracts. Available at: https://ir.lib.uwo.ca/etd/2264/.

[45] Robinson SL, Wolfe Morrison E. The development of psychological contract breach and violation: A longitudinal study. Journal of organizational Behavior. 2000 Aug; 21 (5): $525-46$.

[46] Glavas A, Godwin LN. Is the perception of 'goodness' good enough? Exploring the relationship between perceived corporate social responsibility and employee organizational identification. Journal of business ethics. 2013 Apr 1; 114 (1): 15-27.

[47] Riketta M, Van Dick R. Foci of attachment in organizations: A meta-analytic comparison of the strength and correlates of workgroup versus organizational identification and commitment. Journal of vocational behavior. 2005 Dec 1; 67 (3): 490-510. 
[48] Mahmoudi G, Abdi Talarposhti M. An assessment of agility in selected hospitals of Mazandaran province, Iran. Journal of Basic Research in Medical Sciences. 2018 Jun 10; 5 (3): 32-41.

[49] Giachetti RE, Martinez LD, Sáenz OA, Chen CS. Analysis of the structural measures of flexibility and agility using a measurement theoretical framework. International journal of production economics. 2003 Oct 11; 86 (1): 47-62.

[50] Sidky A, Arthur J, Bohner S. A disciplined approach to adopting agile practices: the agile adoption framework. Innovations in systems and software engineering. 2007 Sep 1; 3 (3): 203-16.

[51] Tsourveloudis NC, Valavanis KP. On the measurement of enterprise agility. Journal of Intelligent and Robotic Systems. 2002 Mar 1; 33 (3): 329-42.

[52] Yusuf YY, Gunasekaran A, Musa A, Dauda M, El-Berishy NM, Cang S. A relational study of supply chain agility, competitiveness and business performance in the oil and gas industry. International Journal of Production Economics. 2014 Jan 1; 147: 531-43.

[53] Salmanoğlu M, Coşkunçay A, Yildiz A, Demirörs O. An Exploratory Case Study for Assessing the Measurement Capability of an Agile Organization. Software Quality Professional. 2018 Mar 1; 20 (2).

[54] Felipe CM, Roldán JL, Leal-Rodríguez AL. An explanatory and predictive model for organizational agility. Journal of Business Research. 2016 Oct 1; 69 (10): 4624-31.

[55] IBM Corp. Released 2011. IBM SPSS Statistics for Windows, Version 20.0. Armonk, NY: IBM Corp.

[56] Piccoli B, De Witte H. Job insecurity and emotional exhaustion: Testing psychological contract breach versus distributive injustice as indicators of lack of reciprocity. Work \& Stress. 2015 Jul 3; 29 (3): 246-63.

[57] Bauer TN, Bodner T, Erdogan B, Truxillo DM, Tucker JS. Newcomer adjustment during organizational socialization: a meta-analytic review of antecedents, outcomes, and methods. Journal of applied psychology. 2007 May; 92 (3): 707.

[58] Ashforth BE, Rogers KM, Corley KG. Identity in organizations: Exploring cross-level dynamics. Organization science. 2011 Oct; 22 (5): 1144-56.

[59] Colman HL, Lunnan R. Organizational identification and serendipitous value creation in post-acquisition integration. Journal of management. 2011 May; 37 (3): 839-60.

[60] Millward LJ, Haslam SA. Who are we made to think we are? Contextual variation in organizational, workgroup and career foci of identification. Journal of Occupational and Organizational Psychology. 2013 Mar; 86 (1): 50-66.
[61] Brickson SL. Athletes, best friends, and social activists: An integrative model accounting for the role of identity in organizational identification. Organization Science. 2013 Feb; 24 (1): 226-45.

[62] Lapointe É, Vandenberghe C, Boudrias JS. Psychological contract breach, affective commitment to organization and supervisor, and newcomer adjustment: A three-wave moderated mediation model. Journal of Vocational Behavior. 2013 Dec 1; 83 (3): 528-38.

[63] Bayram A, Zeybek A. Organizational Identification and Psychological Contract Relationship between Public Employees. International Journal of Trade, Economics and Finance. 2016 Jun; 7 (3). Available at http://www.ijtef.org/vol7/499-AB00014.pdf Accessed on September 2019.

[64] Sulu S, Ceylan A, Kaynak R. Work alienation as a mediator of the relationship between organizational injustice and organizational commitment: Implications for healthcare professionals. International Journal of Business and Management. 2010 Aug 1; 5 (8): 27.

[65] Oreg S, Sverdlik N. Ambivalence toward imposed change: The conflict between dispositional resistance to change and the orientation toward the change agent. Journal of Applied Psychology. 2011 Mar; 96 (2): 337.

[66] Madsen SR, Miller D, John CR. Readiness for organizational change: do organizational commitment and social relationships in the workplace make a difference? Human Resource Development Quarterly. 2005 Jun; 16 (2): 213-34.

[67] Bartels J, Pruyn A, de Jong M. Employee identification before and after an internal merger: A longitudinal analysis. Journal of Occupational and Organizational Psychology. 2009 Mar; 82 (1): 113-28.

[68] Ng TW, Feldman DC, Lam SS. Psychological contract breaches, organizational commitment, and innovation-related behaviors: a latent growth modeling approach. Journal of applied Psychology. 2010 Jul; 95 (4): 744.

[69] Bal PM, De Lange AH, Jansen PG, Van Der Velde ME. Psychological contract breach and job attitudes: A metaanalysis of age as a moderator. Journal of vocational behavior. 2008 Feb 1; 72 (1): 143-58.

[70] Khalili A, Asmawi A. Appraising the impact of gender differences on organizational commitment: Empirical evidence from a private SME in Iran. International Journal of Business and Management. 2012 Mar 1; 7 (5): 100.

[71] Edwards MR, Peccei R. Perceived organizational support, organizational identification, and employee outcomes. Journal of Personnel Psychology. 2010 Feb 26. 